\title{
ENZYMATIC ACTIVITY MEASURED BY MICROCALORIMETRY IN SOIL AMENDED WITH ORGANIC RESIDUES ${ }^{(1)}$
}

\author{
Karina Cenciani ${ }^{(2)}$, Sueli dos Santos Freitas ${ }^{(3)}$, Silvana Auxiliadora \\ Missola Critter ${ }^{(4)} \&$ Claudio Airoldi ${ }^{(5)}$
}

\begin{abstract}
SUMMARY
Enzymatic activity is an important property for soil quality evaluation. Two sequences of experiments were carried out in order to evaluate the enzymatic activity in a soil (Rhodic Eutrudox) amended with cattle manure, earthworm casts, or sewage sludges from the municipalities of Barueri and Franca. The activity of commercial enzymes was measured by microcalorimetry in the same soil samples after sterilization. In the first experiment, the enzyme activities of cellulase, protease, and urease were determined in the soil samples during a three month period. In the second sequence of experiments, the thermal effect of the commercial enzymes cellulase, protease, and urease on sterilized soil samples under the same tretaments was monitored for a period of 46 days. The experimental design was randomized and arranged as factorial scheme in five treatments $x$ seven samplings with five replications. The treatment effects were statistically evaluated by one-way analysis of variance. Tukey's test was used to compare means at $p \leq 0.05$. The presence of different sources of organic residues increased the enzymatic activity in the sampling period. Cattle manure induced the highest enzymatic activity, followed by municipal sewage sludge, whereas earthworm casts induced the lowest activity, but differed from control treatment. The thermal effect on the enzyme activity of commercial cellulase, protease, and urease showed
\end{abstract}

(1) Study extracted from master's thesis of the first author and financed by FAPESP. Received for publication in December 1, 2009 and approved in April 14, 2011.

${ }^{(2)}$ Master by the Program of Agro-environmental Resources Management, Instituto Agronomico - IAC/APTA. PO Box 28, Postal Code 13012-970, Campinas (SP). E-mail: kcencian@gmail.com

(3) Researcher of the Center for Research and Development of Soil and Environmental Resources, IAC/APTA. E-mail: sfreitas@iac.sp.gov.br

(4) Post-Doctorate by the Center for Research and Development of Soil and Environmental Resources, IAC/APTA. E-mail: samcritter@globo.com

(5) Researcher of the Department of Inorganic Chemistry, Chemistry Institute, Universidade Estadual de Campinas - UNICAMP. PO Box 6154, Postal Code 13084-971, Campinas (SP). E-mail: airoldi@iqm.unicamp.br 
a variety of time peaks. These values probably oscillated due to soil physicalchemical factors affecting the enzyme activity on the residues.

Index terms: extracellular enzymes, soil microorganisms, thermal effect.

\title{
RESUMO: ATIVIDADE ENZIMÁTICA AVALIADA POR MICROCALORI- METRIA EM SOLO TRATADO COM DIFERENTES RESÍDUOS ORGÂNICOS
}

\begin{abstract}
A atividade enzimática é uma propriedade importante para avaliação da qualidade do solo. Duas sequências de experimentos foram realizadas com o objetivo de avaliar a atividade enzimática em amostras de solo (Latossolo Vermelho eutroférrico típico), tratadas com esterco bovino, húmus de minhoca ou lodos de esgoto dos municípios de Barueri e Franca. A atividade de enzimas comerciais nas mesmas amostras de solo, após serem esterilizadas, foi medida por microcalorimetria. No primeiro experimento, a atividade das enzimas celulase, protease e urease foi determinada em amostras de solo durante um período de três meses. Na segunda sequência de experimentos, o efeito térmico das enzimas comerciais celulase, protease e urease em amostras de solo, esterilizadas sob os mesmos tratamentos, foi monitorado por um periodo de 46 dias. O delineamento experimental foi inteiramente casualizado, em esquema fatorial cinco tratamentos $x$ sete amostragens, com cinco repetições. O efeito dos tratamentos foi avaliado estatisticamente pela análise de variância. O teste de Tukey foi usado para comparar médias a $p \leq 0,05$. A presença de diferentes fontes de materiais orgânicos aumentou a atividade enzimática durante o período de amostragem. O esterco bovino propiciou os maiores valores, seguido pelos lodos de esgoto. O húmus de minhoca ocasionou os valores mais baixos, mas que diferiram significativamente do tratamento controle. O efeito térmico para a atividade das enzimas comerciais celulase, protease e urease mostrou uma variedade de picos ao longo do tempo. Esses valores oscilaram provavelmente devido aos fatores físico-químicos do solo, alterando a atividade enzimática nos resíduos.
\end{abstract}

Termos de indexação: enzimas extracelulares, microrganismos do solo, efeito térmico.

\section{INTRODUCTION}

Soil quality can be evaluated by its capacity to retain and store water, and to recycle nutrients and energy. Some indicators such as agricultural productivity, physical and chemical properties, erosion, and organic matter contents have been used to monitor soil degradation and its potential for bioremediation (Carter, 2001). Therefore the use of some biological indicators e.g., enzyme activity, carbon dioxide evolution, contents of humic substances and soil porosity could possibly provide additional information on the productivity of a soil under varied conditions, including management practices (Schloter et al., 2003; Shukla et al., 2006).

Enzymes are defined as biological catalysts for specific reactions, which depend on several biotic and abiotic factors such as: $\mathrm{pH}$, temperature, presence or absence of inhibitors, soil organic matter composition, cultivation technique, and other factors, which can directly influence the chemical reactions of these molecules in the soil (Shukla et al., 2006). The chemical and physical processes related to organic matter decomposition may be better understood when accompanied by the activity of several enzymes, not only one, because organic substrates contain a great diversity of organic compounds and ions with active participation in the soil biogeochemical cycles (Caldwell et al., 2005).

The origin of soil enzymes is mainly microbial. They can be found within microbial cells as well as extracellularly in the soil, bound to clay minerals and humic substances. Extracellular enzymes are important for the breakdown of macromolecules such as celluloses, hemicelluloses, and lignin, while intracellular enzymes are the disrupting agents of smaller molecules, e.g., sugars or amino acids (Dick \& Kandeler, 2004). Microbial enzymes can participate in adsorption, oxidation, reduction, hydrolysis, and complexation reactions, converting organic substances into other products to maintain the balance in the soil environment (Dinesh et al., 2004; Caldwell et al., 2005).

In this context, microcalorimetry plays an important role in measuring the total activity of cells and biological tissues. It produces a great number of 
results, since it is a continuous method. The results are however not specific because microcalorimetry quantifies the enthalpy variation during cell metabolism, allowing activity to be monitored over long periods. Since microcalorimetry has the advantage of being specific to the initial and final energy states of a system, it is independent of organisms or reaction pathways (Nunes-Regueira et al., 2002).

Total thermal effect is the result of the catabolic degradation of a substrate, while anabolic reactions contribute little to the final state of equilibrium. In microbial communities, where growth is limited not only by substrates, but also by physical factors such as diffusion processes and porosity, the anabolic enthalpy change (biosynthesis, microbial growth) is likely to be small when compared to catabolic reactions (breakdown of organic substrates, enzymatic activity). Consequently the thermal effect in soils is closely related to respiration, ATP content, microbial biomass, and enzyme activity (Barros \& Feijóo, 2003; Critter et al., 2004a,b; Cenciani et al., 2008).

Some physical and chemical soil properties such as $\mathrm{pH}$, temperature, moisture content, $\mathrm{O}_{2}$ levels, and nutritional conditions are important in the calorimetric study of microbial communities (NúñezRegueira et al., 2002). An isothermal environment is a positive factor for the establishment of adequate conditions for microbial growth and metabolism, and also for measuring the thermal effect (Critter et al., 2001). This is one of reasons to the fact that heat conduction or isothermal microcalorimeters have been recently used in several calorimetric studies, such as in the efficiency of $\mathrm{C}$ utilization by soil microorganisms (Barros \& Feijóo, 2003), microbial activity in composts using microcalorimetry (Laor et al., 2004), thermal effect resulting from the influence of agrochemicals on soil microorganisms (Prado \& Airoldi, 2000; Critter et al., 2004a) and in applications of microcalorimetry and the respiration rate to investigate microbial growth and activity (Critter et al., 2001, 2002; Cenciani et al., 2008).

The purpose of this study was to compare the enzyme activities of cellulase, protease, and urease of soil microorganisms in unsterilized soil samples of a Rhodic Eutrudox, and the contribution of the same enzymes, commercially obtained, in sterilized soil samples by calorimetry

\section{MATERIAL AND METHODS}

\section{Soil Sampling}

Soil samples were collected from an experimental corn field of the Instituto Agronomico, Campinas, State of São Paulo, Brazil. From April to June, the area is used to grow winter cereals: wheat and oat; and from October to December for grain, cereal and fiber species: corn, soybean, peanut, cotton, and sunflower. The soil is characterized as a clayeytextured Rhodic Eutrudox (Soil Survey Staff, 1996). After removal of the top litter layer and larger particles, soil was sampled from the 0-20 cm layer, sieved $(2 \times 2 \mathrm{~mm}$ mesh size $)$ and the moisture content was determined by drying to constant weight at $105^{\circ} \mathrm{C}$

The organic residues cattle manure and earthworm casts were obtained commercially and the sewage sludges collected in the sewage treatment plants of the municipal districts Barueri and Franca, SP, Brazil. In Franca, the sludge was from households and in Barueri sludge from urban-industrial wastewater. In view of the high contents of heavy metals in the composition of sewage sludge from Barueri, the $\mathrm{pH}$ was raised to 12 by prior liming.

The residues were amended separately from the soil samples at a proportion of $25 \%$ on a dry matter basis. Five soil replicates were prepared by mixing $25 \mathrm{~g}$ of each organic material with $75 \mathrm{~g}$ of soil. Control replicates (C) were prepared by weighing $100 \mathrm{~g}$ of soil without additions of organic materials. The enzymatic activity sequence in unsterilized soil samples was recorded during a period of three months. Seven samplings were performed every 15 days, with five replicates, during 91 days. Soil samples amended with different organic residues were stored in open plastic bags and moistened every week to $60 \%$ of the water holding capacity (\%WHC), and maintained in an incubation room at $28 \pm 2{ }^{\circ} \mathrm{C}$. The soil and the organic materials were chemically analyzed at the beginning of the experiment (Table 1).

\section{Enzymes}

Cellulase activity ( $\mu$ g glucose $\mathrm{g}^{-1}$ soil $24 \mathrm{~h}^{-1}$ ) was determined by the method of Hope \& Burns (1987), which measures glucose as the final product of cellulose degradation. Control samples were prepared by adding avicel after the incubation time and immediately before sample centrifugation. The glucose content was determined according to the Nelson-Somogyi method, as described by Hope \& Burns (1987). A Bausch \& Lomb spectrophotometer was used for measurements at $\lambda=520 \mathrm{~nm}$. Cellulase activity was determined by a calibration curve.

Protease activity was determined through the method described by Ladd \& Butler (1972). Tyrosine (Tyr) amino acid concentration was obtained in the soil samples after incubation with sodium caseinate ( $\mu \mathrm{g}$ Tyr $\mathrm{g}^{-1}$ soil $2 \mathrm{~h}^{-1}$ ). Absorbance was measured in a Bausch \& Lomb spectrophotometer at $\lambda=700 \mathrm{~nm}$. The activity of the urease enzyme $\left(\mu \mathrm{g} \mathrm{NH}_{4}{ }^{+}-\mathrm{N} \mathrm{g}^{-1}\right.$ soil $2 \mathrm{~h}^{-1}$ ) was measured by the determination of ammonia released after soil sample incubation with an urea solution, as described by Tabatabai \& Bremner (1972). 
Table 1. Chemical properties of Rhodic Eutrudox soil and the organic residues cattle manure, earthworm casts and municipal sewage sludges from Barueri and Franca

\begin{tabular}{|c|c|c|c|c|c|c|c|c|c|c|}
\hline Treatment & Moisture & pH CaCl${ }_{2}$ & C & $\mathbf{N}$ & $\mathbf{P}$ & Cd & $\mathrm{Cu}$ & $\mathrm{Cr}$ & $\mathrm{Ni}$ & $\mathbf{P b}$ \\
\hline \multicolumn{3}{|c|}{$\%$} & \multicolumn{3}{|c|}{$\mathrm{g} \mathrm{kg}^{-1}$} & & & $\mathrm{mg} \mathrm{kg}^{-1}$ & & \\
\hline Soil & 12.7 & 5.8 & 38.0 & 1.4 & 1.1 & $<0.1$ & 96.0 & 153.2 & 21.9 & 46.0 \\
\hline Cattle manure & 6.6 & 7.3 & 111.0 & 12.2 & 6.3 & 0.7 & 79.1 & 34.1 & 12.2 & 19.4 \\
\hline Earthworm casts & 32.8 & 6.2 & 142.0 & 14.8 & 13.6 & $<0.1$ & 250.8 & 26.4 & 12.4 & 25.4 \\
\hline Barueri sludge & 9.7 & 12.5 & 353.0 & 31.9 & 31.9 & 35.8 & 1639.0 & 803.0 & 724.0 & 256.0 \\
\hline Franca sludge & 10.3 & 6.0 & 411.0 & 51.1 & 1.9 & 1.3 & 350.0 & 1072.0 & 68.2 & 95.9 \\
\hline
\end{tabular}

\section{Microcalorimetry}

A model LKB 2277 Thermal Activity Monitor microcalorimeter, Thermometric AB, Sweden, was used to measure thermal effects in sterilized soil samples. Soil samples were prepared in steel vessels filled with $1.0 \mathrm{~g}$ of soil separately amended with $25 \%$ of different organic materials: cattle manure (CM), earthworm casts (EC) and sewage sludges from the municipal districts of Barueri (BA) and Franca (FR). The vessels were autoclaved at $125 \pm 1^{\circ} \mathrm{C}$ for $20 \mathrm{~min}$. The enzymes (Sigma) tested in this experiment were cellulase from Aspergillus niger, Type XIII protease from Aspergillus saitoi, and Type X urease from Bacillus pasteurii. The specific amounts of enzymes added to the steel vessels were computed according to the average enzymatic activity values in unsterilized soil samples subjected to several amendments, and also based on the previous knowledge of the amounts of final product produced per mg of enzyme. The following amounts of enzymes were tested: $42.34 \mathrm{mg}$ cellulase, $18.64 \mathrm{mg}$ protease, and $10.54 \mathrm{mg}$ urease, previously dissolved in water and introduced into the steel vessels containing the soil samples amended with the organic materials. The vessels were hermetically sealed with Teflon sealing discs to avoid evaporation but ensure the transfer of oxygen and carbon dioxide. The microcalorimeter was calibrated by the release of electrical energy in a thermopile, and the thermal effect within the ampoules was adjusted according to the electrical calibration (Critter et al., 2004a). After thermostatization of the sample ampoules, the thermal power effect associated with the activity of enzymes was recorded as a function of time during a period of 46 days at $25.15 \pm 0.02{ }^{\circ} \mathrm{C}$. The exothermic effect ($\mathrm{Q} / \mathrm{J} \mathrm{g}^{-1}$ soil) obtained was calculated by the integration of area under the power curve $(\Delta \mathrm{P} / \mu \mathrm{W})$ versus time $(\Delta \mathrm{t} / \mathrm{s})$.

\section{Statistical analysis}

The experiment was factorial (five treatments $\mathrm{x}$ seven samplings with five replications) in a randomized design. The percentage standard error of the mean value for each soil amendment was calculated for all incubation periods of the experiments.
Treatment effects were statistically evaluated by oneway analysis of variance. Tukey's test was used to compare means at $\mathrm{p} \leq 0.05$. A linear Pearson's correlation analysis was performed in order to correlate the enzyme activities in unsterilized soil samples to the exothermal effect of enzyme activities in sterilized soil samples.

\section{RESULTS AND DISCUSSION}

\section{Enzymatic activity in unsterilized soil}

\section{Cellulase}

The different composition of organic residues amended to the soil samples stimulated cellulase activity in the soil (Table 2a). A notable aspect was the high activity in the soil samples with cattle manure $\left(188 \mu \mathrm{g}\right.$ glucose $\mathrm{g}^{-1}$ soil $\left.24 \mathrm{~h}^{-1}\right)$ at the beginning of samplings, suggesting that the cellulose present in this residue was quickly assimilated by soil microorganisms. Cellulase activity was reduced after the first sampling, reaching a minimum value on the $31^{\text {st }}$ day of incubation $\left(25.5 \mu\right.$ g glucose $\mathrm{g}^{-1}$ soil $\left.24 \mathrm{~h}^{-1}\right)$, and then increased until the last sampling (151.6 $\mu \mathrm{g}$ glucose $\mathrm{g}^{-1}$ soil $24 \mathrm{~h}^{-1}$ ). Cattle manure was an efficient source of cellulose for microorganisms, as reflected directly in the highest values of sum of cellulolytic activity during the 91 days (Table 2a).

In the samples containing earthworm casts and sewage sludge from Barueri and Franca some oscillations in the cellulase activity were observed. This could be related to cellulase composition and availability to the soil microorganisms. The overall cellulase activity in the soil samples containing earthworm casts was relatively low $(261 \mu \mathrm{g}$ glucose $\mathrm{g}^{-1}$ soil $24 \mathrm{~h}^{-1}$ ), when compared with other organic materials, but values were significantly higher than of the unamended control. These results are probably due to the relatively humified and stable composition that characterizes the earthworm humus (Cenciani et al., 2008). 
The sum of cellulase activity was lower in the sludge from Franca $\left(273.4 \mu \mathrm{g}\right.$ glucose g-1 ${ }^{-1}$ soil $\left.24 \mathrm{~h}^{-1}\right)$ than in sewage sludge from Barueri $(367.7 \mu \mathrm{g}$ glucose $\mathrm{g}^{-1}$ soil $\left.24 \mathrm{~h}^{-1}\right)($ Table $2 \mathrm{a})$, despite the high carbon contents in both sludges (Table 1). But the cellulase activity in Franca samples was higher than in earthworm casts $\left(261.0 \mu \mathrm{g}\right.$ glucose $\mathrm{g}^{-1}$ soil $\left.24 \mathrm{~h}^{-1}\right)$ and the control (148.5 $\mu$ g glucose $\mathrm{g}^{-1}$ soil $\left.24 \mathrm{~h}^{-1}\right)$ during the 91 experimental days (Table 2a). Barueri sludge increased the microbial production of cellulases, reaching the highest value on the $45^{\text {th }}$ day $\left(85.2 \mu\right.$ g glucose $\mathrm{g}^{-1}$ soil $\left.24 \mathrm{~h}^{-1}\right)$. Data showed that BA contained higher levels of $\mathrm{Pb}, \mathrm{Ni}$ and $\mathrm{Mn}$ than FR sludge (Table 1), but that metal concentrations were not high enough to inhibit the cellulase activity.

The differences observed in the cellulase activity between the sludges of different sewage treatment plants suggested that part of the organic carbon was available to the microorganisms. It is possible that a fraction of the cellulose present in the sewage sludge from Franca formed complexes with ions present in the material. Consequently, cellulose would be unavailable for a reaction with the cellulolytic enzymes, rendering the occurrence of cellulose mineralization very difficult (Table 2a). Possibly the ion availability in FR sludge is different from the BA sludge. It is possible that the $\mathrm{pH}$ influences these processes. In relatively acidic soil, as in FR sludge with $\mathrm{pH}$ 6.0, several ions are hydrolyzed and can react with organic compounds to form organic-complexes (Cenciani et al., 2008), differently from the Barueri sludge, with an alkaline $\mathrm{pH}$ of around 12 (Table 1).

Cellulolytic enzymes are indicator molecules of soil biological activity in soils, mainly in the form of celluloses essential for the maintenance of microbial recycling of organic carbon (Dick \& Kandeler, 2004). Results clearly indicate that cellulase activity depends on the chemical properties of the sewage sludge. It can be inferred that the microbial species, capable of degrading the different organic materials, differ significantly in quantity and diversity between the sludges (Kunito et al., 2001).

\section{Protease}

Cattle manure showed great protease activity but there were no significant differences between the amendments tested in the first sampling (Table 2b). Oscillations were observed during the 91 days of incubation showing that soil microorganisms had an increasingly higher proteolysis activity in the samples amended with cattle manure, which were significantly different from the other amendments (Table 2b). The sum of total activity for cattle manure $(49,686.8 \mu \mathrm{g}$ Tyr $\mathrm{g}^{-1}$ soil $2 \mathrm{~h}^{-1}$ ) was higher than for sewage sludge from Barueri (32,769.2 $\mu \mathrm{g}$ Tyr g ${ }^{-1}$ soil $\left.2 \mathrm{~h}^{-1}\right)$.

Protease activity in the soil samples amended with sewage sludge from Barueri did not vary significantly in the 91 incubation days, probably because the decomposition of the complex $\mathrm{N}$ forms in this material represented a certain barrier for microorganisms (Kunito et al., 2001). The data of cellulase activity indicated that the heavy metal concentrations were not high enough to inhibit protease activity.

There were no significant differences between the protease activity of earthworm casts and FR sewage sludge during the sampling period (Table 2b). It is possible that the slow release of humified compounds during the decomposition of earthworm casts was the main cause for small oscillations in the protease activity (Pascual et al., 2002), but these values were lower than those observed in the samples with cattle manure.

These results can be explained by the microbial succession that naturally occurs in soils, in which microbial enzymatic activity is stimulated by the input of organic matter. The chemical compounds are initially processed by indigenous microorganisms into degradable subunits (sugars, amino acids, $\mathrm{NH}_{4}{ }^{+}, \mathrm{NO}_{3}{ }^{-}$), which in turn are used as final electron acceptors by other new groups of microorganisms, while a pool of

Table 2. Sum of cellulase $\left(\Sigma \mu \mathrm{g}\right.$ glucose $\mathrm{g}^{-1}$ soil $\left.24 \mathrm{~h}^{-1}\right)(\mathrm{a})$, protease $\left(\Sigma \mu \mathrm{g}\right.$ Tyr g-1 soil $\left.2 \mathrm{~h}^{-1}\right)$ (b) and urease $\left(\Sigma \mu \mathrm{g} \mathrm{NH}_{4}{ }^{+}-\mathrm{N} \mathrm{g}^{-1}\right.$ soil $\left.2 \mathrm{~h}^{-1}\right)$ (c) activities in Rhodic Eutrudox soil samples (C) amended with cattle manure (CM), earthworm casts (EC), and sewage sludges from Barueri (BA) and Franca (FR) for three months at $25 \pm 2{ }^{\circ} \mathrm{C}$.

\begin{tabular}{|c|c|c|c|c|c|c|c|c|c|c|c|c|c|c|c|}
\hline Day & C & CM & EC & BA & FR & C & CM & EC & BA & FR & C & CM & EC & BA & FR \\
\hline & & & $-\mathrm{a}$ & & & & & -0 & & & & & $-\mathrm{C}$ & & \\
\hline 1 & $36.6^{\mathrm{BC}}$ & $188.0^{\mathrm{A}}$ & $50.9^{\mathrm{B}}$ & $5.0^{\mathrm{C}}$ & $22.7^{\mathrm{C}}$ & $362.4^{\mathrm{B}}$ & $1,092.1^{\mathrm{AB}}$ & $2,104.7 \mathrm{AB}$ & $3,040.8^{\mathrm{A}}$ & $1,692.0 \mathrm{AB}$ & $806.9^{\mathrm{C}}$ & $2,143.3^{\mathrm{A}}$ & $464.5^{\mathrm{C}}$ & $1,762.3^{\mathrm{B}}$ & $2,971.3^{\mathrm{A}}$ \\
\hline 16 & $69.8^{\mathrm{C}}$ & $235.5^{\mathrm{A}}$ & $128.7^{\mathrm{B}}$ & $59.5^{\mathrm{C}}$ & $42.9^{\mathrm{C}}$ & $1,856.4^{\mathrm{D}}$ & $10,685.4^{\mathrm{A}}$ & $5,922.2^{\mathrm{C}}$ & $8,312.9^{\text {B }}$ & $3,438.3^{\mathrm{D}}$ & $1,153.8^{\mathrm{C}}$ & $2,287.4^{\mathrm{B}}$ & $881.6^{\mathrm{C}}$ & $2,254.0^{\mathrm{B}}$ & 4,730 \\
\hline 31 & $90.3^{\mathrm{D}}$ & $261.0^{\mathrm{A}}$ & $159.6^{\mathrm{B}}$ & $126.6^{\mathrm{C}}$ & $87.8^{\mathrm{D}}$ & $1,994.8^{\mathrm{D}}$ & $16,372.5^{\mathrm{A}}$ & $6,572.4^{\mathrm{C}}$ & $12,984.7^{\mathrm{B}}$ & $5,764.7 \mathrm{C}$ & $1,759.1^{\mathrm{C}}$ & $4,659.9^{\mathrm{A}}$ & $2,431.4^{\mathrm{BC}}$ & $3,294.2^{\mathrm{B}}$ & $5,113.4^{\mathrm{A}}$ \\
\hline 46 & $102.4^{\mathrm{C}}$ & $311.8^{\mathrm{A}}$ & $187.0^{\mathrm{B}}$ & $211.8^{\mathrm{B}}$ & $118.8^{\mathrm{C}}$ & $2,329.2^{\mathrm{D}}$ & $28,439.1^{\mathrm{A}}$ & $10,213.9^{\mathrm{C}}$ & $18,480.3^{\mathrm{B}}$ & $8,739.7 \mathrm{C}$ & $2,132.0^{\mathrm{D}}$ & $7,468.1^{\mathrm{A}}$ & $3,175.4^{\mathrm{C}}$ & $4,487.4^{\mathrm{B}}$ & $7,502.5^{\mathrm{A}}$ \\
\hline 61 & $116.5^{\mathrm{D}}$ & $385.4^{\mathrm{A}}$ & $210.0^{\mathrm{B}}$ & $233.8^{\text {B }}$ & $164.4^{\mathrm{C}}$ & $2,678.7^{\mathrm{D}}$ & $36,881.9^{\mathrm{A}}$ & $11,880.2^{\mathrm{C}}$ & $23,516.6^{\text {B }}$ & $11,707.8^{\mathrm{C}}$ & $2,966.9^{\mathrm{D}}$ & $10,186 \cdot 3^{\mathrm{A}}$ & $4,256.6^{\mathrm{C}}$ & $5,494.8^{\text {В }}$ & $9,396$. \\
\hline 76 & $133.7^{\mathrm{D}}$ & $504.2^{\mathrm{A}}$ & $233.2^{\mathrm{C}}$ & $324.0^{\mathrm{B}}$ & $220.6^{\mathrm{C}}$ & $3,265.2^{\mathrm{D}}$ & $43,795.6^{\mathrm{A}}$ & $14,325.8^{\mathrm{C}}$ & $27,993.2^{\mathrm{B}}$ & $15,230.8^{\mathrm{C}}$ & $3,647.6^{\mathrm{D}}$ & $16,137.3^{\mathrm{A}}$ & $6,274.4^{\mathrm{C}}$ & $6,607.9^{\mathrm{C}}$ & $13,446.1^{\mathrm{B}}$ \\
\hline 91 & $148.5^{\mathrm{D}}$ & $655.9^{\mathrm{A}}$ & $261.0^{\mathrm{C}}$ & $367.7^{\text {B }}$ & $273.4^{\mathrm{C}}$ & $3,556.2^{\mathrm{D}}$ & $49,686.8^{\mathrm{A}}$ & $17,052.0^{\mathrm{C}}$ & $32,769.2^{\text {B }}$ & $18,773.4^{\mathrm{C}}$ & $4,003.4^{\mathrm{E}}$ & $24,554.8^{\mathrm{A}}$ & $9,020.5^{\mathrm{D}}$ & $10,667.4^{\mathrm{C}}$ & $19,359.4^{\mathrm{B}}$ \\
\hline
\end{tabular}

Values followed by the same letter in the rows, for each enzyme activity evaluated, are not different at $\mathrm{p} \leq 0.05$. 
persistent substances remains (Dick \& Kandeler, 2004; Caldwell et al., 2005).

\section{Urease}

Urea is a byproduct of urease activity. An important aspect in this experiment was the increase in urease activity detected only 76 days after the first sampling $\left(5,951.0 \mu \mathrm{g} \mathrm{NH}_{4}{ }^{+} \mathrm{N} \mathrm{g}^{-1}\right.$ soil $\left.2 \mathrm{~h}^{-1}\right)$ (Table 2c). Cattle manure and the BA and FR sewage sludges contained available urea, which should have stimulated the urease production earlier. Possibly the $\mathrm{N}$-rich substrates capable of stimulating the urease action require more time for degradation. According to our results before the $76^{\text {th }}$ day, the existing and available nitrogen in the soil amended with the organic materials was probably sufficient for the entire microbial metabolism (Dick \& Kandeler, 2004). It is also possible that the nitrogen used by soil microorganisms before the $76^{\text {th }}$ day was provided by enzymatic activity occurring before urease action, e.g., by protease activity.

In the samples amended with cattle manure, a decrease in urease activity occurred 16 days after incubation $\left(144.1 \mu \mathrm{g} \mathrm{NH}_{4}^{+}-\mathrm{N} \mathrm{g}^{-1}\right.$ soil $\left.2 \mathrm{~h}^{-1}\right)$, later followed by stabilization and subsequent increase, reaching high values at the end of the incubation period $\left(8,417.5 \mu \mathrm{g} \mathrm{NH}_{4}{ }^{+}-\mathrm{N} \mathrm{g}^{-1}\right.$ soil $\left.2 \mathrm{~h}^{-1}\right)$. Cattle manure is a rich $\mathrm{N}$-source, and has a high percentage of urea that comes from cattle urine and solid wastes (Albiach et al., 2000). As in the case of the cellulase and protease activities, cattle manure resulted in the highest urease activity in the incubation period $\left(24,554.8 \mu \mathrm{g} \mathrm{NH}_{4}{ }^{+}\right.$$\mathrm{N} \mathrm{g}^{-1}$ soil $2 \mathrm{~h}^{-1}$ ) (Table 2c) of all organic residues tested.

Franca sludge induced oscillations in urease activity until the $61^{\text {st }}$ day and an increase until the end of experiment (91 days). Because of the high $\mathrm{N}$ contents in this material $\left(51.1 \mathrm{~g} \mathrm{~kg}^{-1}\right.$ ) (Table 1), urease activity was quite pronounced. BA sludge and earthworm cast did not differ significantly, but induced increases in the urease activity $(4,059.5$ and $2,746.0 \mu \mathrm{g} \mathrm{NH}_{4}{ }^{+}-\mathrm{N} \mathrm{g}^{-1}$ soil $2 \mathrm{~h}^{-1}$, respectively) over the control, but not as high as those observed for cattle manure $\left(8,417.5 \mu \mathrm{g} \mathrm{NH}_{4}{ }^{+}-\mathrm{N} \mathrm{g}^{-1}\right.$ soil $\left.2 \mathrm{~h}^{-1}\right)$ and FR sludge $\left(5,913.3 \mu \mathrm{g} \mathrm{NH}_{4}{ }^{+}-\mathrm{N} \mathrm{g}^{-1}\right.$ soil $\left.2 \mathrm{~h}^{-1}\right)$ (Table 2c). The association between humic substances and ureases in earthworm casts can possibly explain the low enzymatic activity, since extracellular enzyme activities are stabilized in the soil by their association with organic and inorganic colloids, acting as a fundamental gateway for extracellular urease stabilization and playing an important role in both soil microbial ecology and nutrient availability for plants and soil biomass (Marzadori et al., 2000; Benitez et al., 2005). Nevertheless, an increase was observed after 76 days, suggesting the presence of urea.

The lower values of urease activity in the samples amended with BA sludge than with FR sludge and cattle manure could be due to the fact that ureases can be associated with clay particles, which provide most of the surface available for interaction with microorganisms (Benitez et al., 2005). However, heavy metals and ureases in soils can occupy the same sites on clays. Thus, the presence of heavy metals in soils can decrease the active sites on the clay surface for microorganisms and decrease their enzymatic activities (Kandeler et al., 2000).

The study of the enzymes involved in the nutrient biogeochemical cycles, as of cellulase, protease, and urease suggests that these represent strong bioindicators of soil microbial activity, in addition to the $\mathrm{C}$ and $\mathrm{N}$ mineralization processes, bioreactions, and humification of soil organic matter. All these processes are fundamental for soil aggregation, fertility, and availability of essential elements to plants (Kunito et al., 2001; Caldwell et al., 2005; Shukla et al., 2006).

\section{Cellulase}

The activity of cellulase enzyme from Aspergillus niger was monitored by the calorimetric method in the presence of several organic residues in sterilized Rhodic Eutrudox soil samples for 46 days. Depending on the amendments, the humic material induced a higher thermal effect during the first four days than the other organic residues. A high exothermal effect was observed for cattle manure during the first three days, due to its cellulose-rich composition that is a readily available nutrient source (Gattinger et al., 2007), but not as pronounced as in samples containing earthworm casts, as it decreased after the beginning of incubation (Figure 1a). The exothermal effect was result of interactions of the enzyme with different substrates, since the soil had been sterilized and had no microbial activity. It is possible that the enzymatic reactions in the soil samples occurred parallel to reactions such as oxidation, reduction and complexation with energy release; all of them were monitored.

The cellulase activity in unsterilized soil samples differed in relation to the power-time curves obtained with the commercial enzymes tested in this study. Differences can be supported by the fact that cellulase activity measured in unsterilized samples corresponded to a group of cellulases that were not discriminated by the calorimetric method. Cellulase exists in a number of chemical compositions (Dilly \& Nannipieri, 2001), of which only one was tested in our experiment. The presence of available cellulose and the direct addition of cellulase enzyme induced a quick enzymatic reaction, resulting in higher thermal effect values released from the steel ampoules than in other amendments (Figure 1b).

Similar to earthworm casts, the BA sludge led to an increase in cellulase activity in the first four days, followed by a decrease until reaching a low activity level. However, an increase in the thermal effect was observed on the $26^{\text {th }}$ day of incubation. Cellulase activity in samples amended with FR sludge was low 
at the beginning of the experiment, increased on the fourth and eighth day and returned to low values by the end (46 $6^{\text {th }}$ day), similarly to what occurred with earthworm casts and Barueri sludge.

Control samples showed a higher cellulase activity than earthworm casts and cattle manure near the $8^{\text {th }}$ and $15^{\text {th }}$ day. This fact can be explained by the availability of cellulose compounds in the soil for the enzymatic reaction only around this period. In relation to other amendments, these compounds may have been degraded at the beginning of the calorimetric measurements, thus resulting in lower power-time curves than the control on the $15^{\text {th }}$ day. After a high cellulase activity was observed between the $2^{\text {nd }}$ and $4^{\text {th }}$ day, the thermal effect decreased after the $11^{\text {th }}$ day, maintaining low values until incubation ended. Our results demonstrated the interactions between enzymes and soil particles (Pascual et al., 2002), regardless of the microbial activity, and that the reactions involved in this process are continuous for 46 days. In this case, a spontaneous enzymatic process occurs and is energetically favorable, since the reactions measured are predominantly exothermic.

\section{Protease}

Significant thermal effect increases were observed during the first 11 days of the calorimetric experiment for cattle manure and FR sewage sludge (Figure 1b).

An increase in the thermal effect was observed in samples amended with earthworm casts around the $15^{\text {th }}$ day of incubation and followed by a decrease, due to its more stable composition. The thermal effect curves around the $26^{\text {th }}$ day were found to be similar for the amendments tested, reaching maximum values on the $36^{\text {th }}$ day, despite different numerical values and decreases until the final samplings. These results suggest a favorable condition for substrate degradation by proteases in all organic materials. Initial reactions modify the system to a condition of maximum activity, depending on the availability of organic substrates.

Protease activity in samples amended with BA sludge showed lower values than of other amendments, but an increase was observed around the $36^{\text {th }}$ day, lower only than of earthworm casts. The absence of organic matter added to the control samples and small amounts of organic nitrogen $\left(1.4 \mathrm{~g} \mathrm{~kg}^{-1}\right)$ (Table 1) could explain the low protease exothermal effect.

\section{Urease}

The addition of organic materials in several chemical compositions, as observed for cellulases from Aspergillus niger and for proteases from Aspergillus saitoi also stimulated the activity of ureases from Bacillus pasteurii, monitored by microcalorimetry (Figure 1c).

Urease activity showed thermal effect oscillations in the soil samples amended with Barueri and Franca sludges during the experimental period. Power-time peaks were detected between the $8^{\text {th }}$ and $15^{\text {th }}$ day of microcalorimetric measurements for both amendments (Figure 1c), suggesting that the action of the enzymes tested with the sludge substrates may have occurred at several stages (Pascual et al., 2002), as discussed earlier.

With regard to the urease activity in sterilized samples with cattle manure no high thermal effect values were detected, since only one peak was observed near the $11^{\text {th }}$ day of the experiment. Therefore, urea
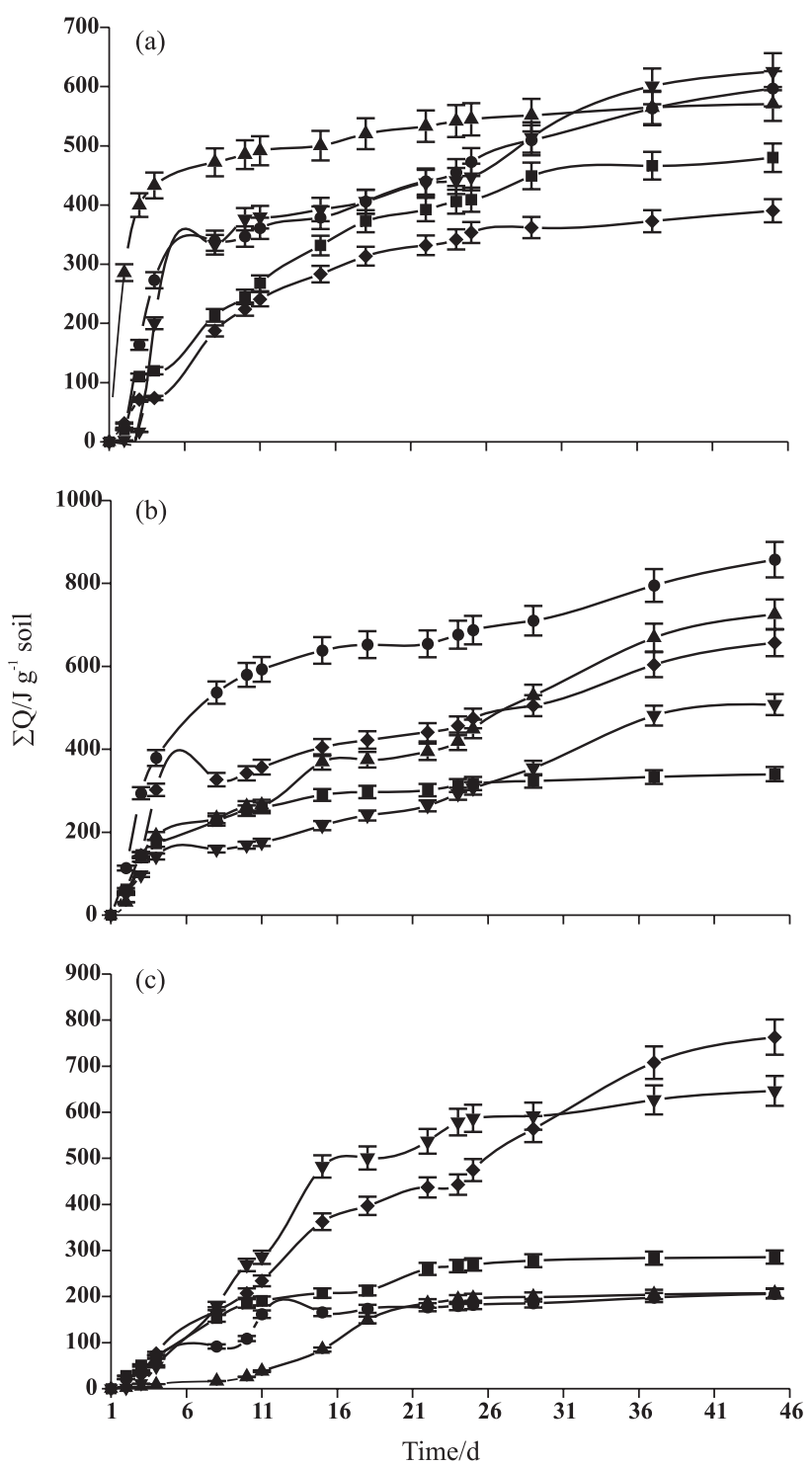

Figure 1. Sum of results $\left(-\Sigma \mathrm{Q} / \mathrm{J} \mathrm{g}^{-1}\right.$ soil) of cellulase total exothermic thermal effect (a), protease total exothermic thermal effect (b) and urease total exothermic thermal effect (c) in sterilized Rhodic Eutrudox soil samples ( $\square$ ) amended with cattle manure (O), earthworm casts $(\Delta)$, and sewage sludges from Barueri $(\nabla)$ and Franca $(\diamond)$ for 46 days at $25.15 \pm 0.02{ }^{\circ} \mathrm{C}$. The toolbar $(\mid)$ is added to each average value and represents the least significant difference between treatments for each sampling day. 
originated from bovine liquid excreta and solid excrements (Marinari et al., 2000) may have been insufficient to increase the thermal effect of urease. Earthworm casts did not increase the urease activity to levels as high as in the sewage sludges; however one activity peak was detected on the $18^{\text {th }}$ day, followed by a decrease and then by low values until the end of incubation period. The stable composition of earthworm casts could explain the observed values.

There were no correlations between enzymatic activity in unsterilized soil and the activity of these enzymes treated in a laboratorial purification process and applied to the sterilized soil (data not shown). The reason for the absence of correlation between the parameters analyzed is clear: the reactions involved in each case are quite different. The commercial enzymes were purified and were rather different from the enzymes in unsterilized soil.

\section{CONCLUSIONS}

1. The addition of cattle manure to the soil induced the highest activity of cellulase, protease and urease, which are enzymes directly related to the biogeochemical cycling of $\mathrm{C}$ and $\mathrm{N}$.

2. Microcalorimetry is a powerful tool for analyzing microbial or enzymatic activity in the soil and sensitive to detect the effect of purified enzymes added to sterilized soil samples.

3. The enzymatic activity measured by microcalorimetry in sterilized soil samples did not correlate with the enzymatic activity of microorganisms in unsterilized soil samples.

\section{ACKNOWLEDGEMENTS}

The authors are indebted to the State of São Paulo Research Foundation (FAPESP) for financial support and for a grant to S.A.M.C., and to the National Council for Scientific and Technological Development (CNPq) for a grant to C.A.

\section{LITERATURE CITED}

ALBIACH, R.; CANET, R.; POMARES, F. \& INGELMO, F. Microbial biomass content and enzymatic activities after the application of organic amendments to a horticultural soil. Biores. Technol., 75:43-48, 2000.

BARROS, N. \& FEIJÓO, S. A combined mass and energy balance to provide bioindicators of soil microbiological quality. Biophys. Chem., 104:561-572, 2003.

BENITEZ, E.; SAINZ, H. \& NOGALES, R. Hydrolytic enzyme activities of extracted humic substances during the vermicomposting of a lignocellulosic olive waste. Biores. Technol., 96:785-790, 2005.
CALDWELL, B.A. Enzyme activities as a component of soil biodiversity: A review. In: INTERNATIONAL SYMPOSIUM ON IMPACTS OF SOIL BIODIVERSITY ON BIOGEOCHEMICAL PROCESSES IN ECOSYSTEMS, 2004, Taipei, Taiwan.; Pedobiology, 49:637644,2005

CARTER, M.R. Organic matter and sustainability. In: REES, B.C.; BALL, B.C.; CAMPBELL, C.D. \& WATSON, C.A., eds. Sustainable management of soil organic matter. Wallingford, CAB International, 2001. p.9-22.

CENCIANI, K.; FREITAS, S.S.; CRITTER, S.A.M. \& AIROLDI, C. Microbial enzymatic activity and thermal effect in a tropical soil treated with organic materials. Sci. Agric., 65:674-680, 2008 .

CRITTER, S.A.M.; FREITAS, S.S. \& AIROLDI, C. Calorimetry versus respirometry for the monitoring of microbial activity in a tropical soil. Appl. Soil Ecol, 18:217-227, 2001.

CRITTER, S.A.M.; FREITAS, S.S. \& AIROLDI, C. Microbial biomass and microcalorimetric methods in tropical soils. Thermochim. Acta, 394:145-154, 2002.

CRITTER, S.A.M.; FREITAS, S.S. \& AIROLDI, C. Comparison of microbial activity in some Brazilian soils by microcalorimetric and respirometric methods. Thermochim. Acta, 410:35-46, 2004a.

CRITTER, S.A.M.; FREITAS, S.S. \& AIROLDI, C. Microcalorimetric measurements of the metabolic activity by bacteria and fungi in some Brazilian soils amended with different organic matter. Thermochim. Acta, 417:275281, 2004b.

DICK, R.P. \& KANDELER, E. Enzymes in soils. In: HILLEL, D., ed. Encyclopedia of soils in the environment. Oxford, Elsevier, 2004. p.448-455.

DILLY, O. \& NANNIPIERI, P. Response of ATP content, respiration rate and enzyme activities in an arable and a forest soil to nutrient additions. Biol. Fert. Soils, 34:34$64,2001$.

DINESH, R.; SURYANARAYANA, M.A.; CHAUDHURI, S.G. \& SHEEJA, T.E. Long-term of leguminous cover crops on the biochemical properties of a sandy clay loam Fluventic Sulfaquent in a humid tropical region of India. Soil Tillage Res., 77:69-77, 2004.

GATTINGER, A.; HÖFLE, M.G.; SCHLOTER, M.; EMBACHER, A.; BÖHME, F.; MUNCH, J.C. \& LABRENZ, M. Traditional cattle manure application determines abundance, diversity and activity of methanogenic Archaea in arable European soil. Environ. Microbiol., 9:612-624, 2007.

HOPE, C.F.A. \& BURNS, R.G. Activity, origins and location of cellulase in a silt loam soil. Biol. Fert. Soils, 5:164-170, 1987.

KANDELER, E.; TSCHERKO, D.; BRUCE, K.D.; STEMMER, M.; HOBBS, P.J.; BARDGETT, R.D. \& AMELUNG, W. Structure and function of the soil microbial community in microhabitats of a heavy metal polluted soil. Biol. Fert. Soils, 32:390-400, 2000. 
KUNITO, T.; SAEKI, K.; SHIGEKO GOTO, S.; HAYASHI, H.; OYAIZU, H. \& MATSUMOTO, S. Copper and zinc fractions affecting microorganisms in long-term sludge amended soils. Biores. Technol., 79:135-146, 2001.

LADD J.N. \& BUTLER, J.H.A. Short-term assays of soil proteolytic enzyme activities using proteins and dipeptide derivatives as substrates. Soil Biol. Biochem., 4:19-30, 1972 .

LAOR, Y.; RAVIV, M. \& BORISOVER, M. Evaluating microbial activity in composts using microcalorimetry. Termochim. Acta., 420:119-125, 2004.

MARINARI, S.; MASCIANDARO, G.; CECCANTI, B. \& GREGO, S. Influence of organic and mineral fertilizers on soil biological and physical properties. Biores. Technol., 72:9-17, 2000.

MARZADORI, C.; FRANCIOSO, O.; CIAVATTA, C. \& GESSA, C. Activity and stability of jack bean urease in the presence of peat humic acids obtained using different extractants. Biol. Fert. Soils, 32:415-420, 2000.

NÚÑEZ-REGUEIRA， L.; NÚÑEZ-FERNANDEZ， O.; RODRIGUEZ AÑÓN, J.A. \& CASTIÑEIRAS, J.P. The influence of some physicochemical parameters on the microbial growth in soils. Termochim. Acta, 394:1232131, 2002.
PASCUAL, J.A.; MORENO, J.L.; HERNÁNDEZ, T. \& GARCÍA, C. Persistence of immobilised and total urease and phosphatase activities in a soil amended with organic wastes. Biores. Technol., 82:73-78, 2002.

PRADO, A.G.S. \& AIROLDI, C. Effect of the pesticide 2,4-D on microbial activity of the soil monitored by microcalorimetry. Thermochim. Acta, 349:17-22, 2000.

SCHLOTER, M.; DILLY, O. \& MUNCH, J.C. Indicators for evaluating soil quality. Agric. Ecosyst. Environ., 98:255262, 2003.

SHUKLA, M.K.; LAL, R. \& EBINGER, M. Determining soil quality indicators by factor analysis. Soil Tillage Res., 87:194-204, 2006

SOIL SURVEY STAFF. Keys to soil taxonomy. 7.ed. Washington, DC, U.S. Department of Agriculture, 1996. $644 \mathrm{p}$.

TABATABAI, M.A. \& BREMNER, J.M. Assay of urease activity in soil. Soil Biol. Biochem., 4:479-487, 1972. 
